\section{Defoliant companies can be sued}

A US federal judge ruled last week that five chemical companies which produced the defoliant "agent orange" can be sued by Vietnam veterans. The veterans claim that they were injured by exposure to the chemical, and that their children were deformed. Agent Orange contains the defoliant 2,4,5-T, suspected of containing the toxic contaminant dioxin; it was extensively used in Vietnam between 1962 and 1971.

The veterans want a trust fund to be set up and financed by the five chemical companies - Dow Chemical, Monsanto, Thompson Hayward Chemical Company, Hercules Inc, and Diamond Shamrock for the benefit of those who, they claim, suffered as a direct or indirect result of exposure to the defoliant. According to the veteran's attorney, claims against the companies could be $\$ 40,000$ million.

The companies had contended that the 362 veterans are entitled only to veteran's medical benefits, and that the suits should be tried individually in state courts. However, Judge George C Pratt ruled that a

suit could be brought against the companies. The US Defense Department was accused last week of severely underestimating the number of soldiers exposed to Agent Orange during operations in Vietnam. Although the Pentagon has until recently said that all combat zones sprayed with the defoliant were free of army personnel, a report issued last Saturday by the General Accounting Office, the investigatory arm of Congress, said that at least 5,900 marines were within a third of a mile of the areas while or immediately after they were being sprayed. The GAO also says that a further 16,000 marines were within a third of a mile of the sprayed areas within four weeks of the spraying, and it called the army's contention that troops did not enter the area until six weeks afterwards as "inaccurate". In a letter to Senator Charles Percy who had requested the GAO investigation, the Department of Defense admitted that "the chances that ground troops were exposed to herbicide Orange are higher than DOD previously acknowledged".

\section{UK radical scientists ten years on}

THE 10th anniversary of the founding of the British Society for Social Responsibility in Science was celebrated in London last week by a congenial gathering of 200 activists representing a span of 60 years of experience of radical and socialist approaches to science. Five speakers analysed the past and present successes of the "largest single grouping of radical scientists in Europe".

Maurice Wilkins, president of the society, evoked the social atmosphere requiring new approaches to the practice of science by emphasising the turbulent state of world affairs. "Things have changed a very great deal in a very short time. We have seen a continuous disintegration and degeneration of our institutions in modern society over the past 50 years. This disintegration has certain advantages since it increases the possibility of getting outside our conditions. It is difficult to overestimate how strong our social conditioning is and BSSRS correctly has been concerned to show that science cannot escape from these conditions."

Joseph Needham, who is as close to a patron saint as is possible for a political organisation to have, presented a unique mixture of Christianity and socialism with a blessing for BSSRS' past and future work. He affirmed his conviction in the achievements of socialism. "Socialism has been an outstanding success in China which was absolutely medieval in character in the 1940 s. I think we have to recognise that India will never get anywhere unless it follows the Chinese way."

Strong continuities exist between the issues of the 30 s science movement and those of present groups. Racism, science in war, organising scientific workers, developing links with left wing movements, demystifying science to a larger audience and the position of women in science are all issues that lie outside mainstream "establishment science". One of the great achievments of the $30 \mathrm{~s}$ movement according to Needham was the campaign leading to the eventual construction of the Anderson air-raid shelters prior to the second world war. "We knew it was important and possible and in spite of government indifference we shamed thern into doing it."

Speakers, Dorothy Griffiths, Jonathan Rosenhead and Mike Cooley outlined BSSRS recent history and immediate future plans. In terms of analysis, the group has moved away from the "useabuse" model of science and technology and is concentrating on developing its understanding of how science is thoroughly integrated into the social fabric through its employment in profitable economic production, its use in social control technology and its use as "a justification for social inequality based on class, race and sex." New activities include a formal Women's Caucus, a working group to criticise the UK government's proposal to count and predict the size of Britain's black population, particularly the racial origin in the 1981 census, and a working group that will provide an information service to trade unions on the likely impact of the proposed introduction of microprocessor based technologies in particular workplaces. proposed introduction of a question on
London meeting calls for end to psychiatric abuse

THE recent meeting in London of the World Psychiatric Association focused attention, once again, on the use of psychiatry for political repression. Although the 1977 Honolulu Congress of the WPA formally condemned psychiatric abuse, there has so far been little concrete action from its special "Committee to Review the Abuse of Psychiatry". Ad hoc pickets at the meeting and Amnesty International in its formal letter to the WPA executive, stressed the need for firm and expeditious action from the Review Committee.

The Amnesty appeal stressed the "consistent pattern" of psychiatric abuse in Romania and the Soviet Union, particularly the latter. Details of over $\mathbf{4 0}$ recent Soviet cases were appended, with "symptoms" ranging from Seventh Day Adventism (Eugenius Darguzes) to membership of an unofficial Marxist discussion group (Alehsandr Skobov) and from organising an independent trade union (Vladimir Klebanov) to proposing Academician Andrei Sakharov as a candidate for the election to the Supreme Soviet (Vladimir Tsurikov). In spite of the recent criticism of "Snezhnevskiism" (Nature 11 October, page 419) Snezhnevskii-type diagnoses of "sluggish schizophrenia" continue - as does the "treatment" of dissent by massive doses of neuroleptic drugs.

Perhaps one of the most telling comments on psychiatric abuse is the fact that the occasional transfer of a dissident such as M Kukobaka (charged with "antiSoviet slander") from psychiatric hospital to trial and prison is viewed by Soviet human rights campaigners as a qualified triumph.

Vera Rich

\section{Galileo formally reprieved}

POPE John Paul II has called for a formal reversal of the Catholic Church's verdict on Galileo, who in 1633 was condemned by the Roman inquisition and placed under house arrest for his heliocentric theory of the solar system. The Pope was addressing a special session of the Vatican's Pontifical Academy of Sciences, held to mark the centenary of the birth of Albert Einstein.

He quoted the Pastoral Constitution Gaudium et Spes No 36/2 of the second Vatican Council, which deplores "certain habits of mind sometimes found too among Christians, which do not sufficiently attend to the rightful independence of science. The arguments and conflicts which they spark lead many minds to conclude that faith and science are mutually opposed". These words, said the Pope, related in particular to the Galileo case. 